\title{
Evaluation of Facial Asymmetry Using Soft-Tissue Thickness for Forensic Purposes
}

\author{
Evaluación de la Asimetría Facial Mediante el Grosor de Tejidos Blandos para Propósitos \\ Forenses
}

\begin{abstract}
"Sebastián René Torres Muñoz; ***Mario Cantín; ****Francisco Javier Pérez Rojas \& *Iván Suazo Galdames
\end{abstract}
TORRES M. S. R.; CANTIN, M.; PÉREZ R. F. J. \& SUAZO, G. I. Evaluation of facial asymmetry using soft-tissue thickness for forensic purposes. Int. J. Morphol., 29(3):1033-1039, 2011.

SUMMARY: Facial reconstruction for forensic sculpture aims to reproduce the face of an individual for identification. This technique is based on the knowledge of the facial soft-tissue thickness, which differs in terms of sexual dimorphism. However, in terms of asymmetry, the real significance of the soft-tissue thickness on both sides of the face is not considered to make an approximation of the morphofacial characteristics of an individual. This study analyzed the facial tissue thickness of 32 adult Spanish corpses of both sexes in six bilateral cephalometric landmarks through the needle puncture technique, comparing the measurements of right and left sides. No significant differences were found when comparing the soft-tissue thickness on the right and left sides in the total sample ( $\mathrm{p}<0.05$ ), or when comparing the values in men and women $(\mathrm{p}<0.05)$. The facial morphology is created by internal and external forces exerted on the soft tissue and influenced by their evolutionary development in vivo, where asymmetry parameters have a genetic and muscular determination, which in normal individuals do not represent a significant difference in the process of reconstruction of forensic sculpture, and can reliably standardize the entire information of facial thickness to the right or left side of the face.

KEY WORDS: Facial asymmetry; Facial reconstruction; Tissue thickness; Medicolegal identification.

\section{INTRODUCTION}

Forensic anthropology is the application of the Biological or Physical Anthropology sciences to the legal process (American Board of Forensic Anthropology, 2003), raising the biological reconstruction of an individual until his/her death (Iscan, 1981). In the case of the corpse of a known individual, testimony recognition is sufficient. Furthermore, in the case of a corpse of an unknown individual, which is in good preservation, traditional techniques such as fingerprinst, anthropometric measurements, facial physiognomy, or dental characteristics are adequate. However, in cases of bodies with aspects of undefined products of putrefaction processes or in case of complete or isolated bones, traditional techniques do not provide an effective resolution for the recognition, and therefore, one must resort to other techniques of forensic medicine and forensic dentistry (Romo Pizarro, 2000).
Craniofacial reconstruction by forensic sculpture is the art or science of reproducing the face of the skull of a subject for medico-legal identification purposes (Teke, 2004; El-Mehallawi \& Soliman, 2001). This technique is based on the knowledge of craniofacial soft-tissue thickness, from which the modeling of different facial integument tissues on the skull bone is done to finally form the face of a given subject (Fink \& Neave, 2005).

Soft-tissue thickness, which varies depending on genetic determinants and their interaction with the environment (Smith \& Buschang, 2001), exhibits significant differences in a craniofacial reconstruction (Rhine \& Campbell, 1980; Dumont, 1986; Manhein et al., 2000; El-Mehallawi \& Soliman; Wilkinson, 2002; Suazo et al., 2007a, 2007b ; Suazo et al., 2008). These differences

\footnotetext{
* Universidad de Talca, Talca, Chile.

** Departamento de Odontología Integral, Facultad de Medicina, Universidad de La Frontera, Temuco, Chile.

*** Facultad de Ciencias de la Salud, Universidad Autónoma de Chile, Sede Talca, Chile.
} 
are mainly in terms of sexual dimorphism. Women have a higher development in the labial region, when compared with that of the chin. In men, there is a greater growth in the pogonion and upper lip, and less-developed lower lip.

However, in terms of asymmetry, the real significance of craniofacial tissue thickness on both sides of the face is not considered when making an approximation of the morphofacial characteristics of an individual. It has been suggested that asymmetry exists in the thickness of homologous tissues for each sex, which determines the presence and consolidation of sexual characteristics, contributing to the assessment of facial expressive characteristics in each individual (Perrett et al., 1998; Meyer-Marcotty et al., 2010).

Usually, asymmetries in left-right axis are established at the embryonic stage through the expression of genes Nodal, Lefty, and Pitx2 (Oki et al., 2009; Schlueter $\&$ Brand, 2007); in addition, muscle imbalance (Ciochon et al., 1997; Kiliaridis et al., 1996) can also cause changes in the facial structures (Brennan \& Antonyshyn, 1996).

Koehler et al. (2004) reported the presence of asymmetries in the craniofacial tissues at lips, periorbital area, jaw, and cheekbones, which was found to be further developed in men than in women. In addition, they also described a strong association between masculinity and the range of facial asymmetry for both the sexes. It has been shown that facial expressions cause a considerable amount of facial asymmetry that is more intense on the left side of the face (Mitra \& Liu, 2004); this has become a useful tool for identification of humans under expression variations (Liu et al., 2002). However, this asymmetry has not been established in subjects without facial expression. A perfect bilateral symmetrical face is almost a theoretical concept, because it rarely occurs in nature, and it has not yet been determined whether the facial tissues vary significantly on both sides of the face when making a facial reconstruction for forensic purposes.

With this background, the purpose of this research was to determine whether there are significant differences in the thickness of the facial tissue of bilateral landmarks, measured on both sides of the face in a series of adult cadavers.

\section{MATERIAL AND METHOD}

Thirty-two cadavers, obtained from the Laboratory of Human Anatomy, University Cardenal Herrera, Valencia, Spain, and preserved by intravascular injection of formaldehyde, with a normal body mass index (BMI) of $18.5-24.9 \mathrm{~kg} / \mathrm{m}^{2}$ and without scars or facial deformities were studied. All cadavers had a dolichocephalic biotype.

The sample consisted of 16 men and 16 women (aged between 24 and 50 years). In each cadaver, six bilateral cephalometric landmarks were identified to compare the left and right sides (Table I). All landmarks were located by palpation from the facial soft-tissue surface.

At each landmark, measurement of the soft-tissue thickness was performed through the needle puncture technique following the protocol used by Suazo et al. (2007a, 2008).

The measurements were tabulated and correlations were performed with sex and thickness measurements of the left and right sides. Statistical analysis was performed using nonparametric t-test for independent samples. The differences were considered significant if the value of $p$ was $<0.05$.

Table I. Description of bilateral cephalometric landmarks.

\begin{tabular}{ll}
\hline Cephalometric landmarks & Description \\
\hline Superciliary & $\begin{array}{l}\text { The most outstanding point of the frontal eminence in the soft tissue. Corresponds to the lateral } \\
\text { point located in the most prominent part of the frontal bone. } \\
\text { Centered in eye pupil, just above the eyebrows in the soft tissue. Corresponds to the highest point of } \\
\text { each orbital bone. } \\
\text { In line with the lateral edge of the eye in the middle of the zygomatic process of the soft tissue. } \\
\text { Corresponds to the point on the outer corner of the orbital cavity. } \\
\text { Exocanthion }\end{array}$ \\
$\begin{array}{l}\text { Centered in eye pupil, just below the bottom margin of the orbit in the soft tis sue. Corresponds to the } \\
\text { lowest point in the bottom margin of each orbital bone. }\end{array}$ \\
The most lateral curvature of the zygomatic bone in soft tissue. Corresponds to the most outer point \\
of the zygomatic bone, viewed from the front. \\
The angle of the jaw in the soft tissue. Corresponds to the upper ledge point of the angle formed by \\
the union of the ramus and body of the mandible in the posterior region in the bone.
\end{tabular}




\section{RESULTS}

The results of the nonparametric statistical analysis of the measured landmarks, regardless of sex, are presented in Table II. In the test of related samples, none of the landmarks showed a significant difference when comparing the right and left in the total sample ( $\mathrm{p}<0.05)$ (Table III). Subsequent analysis was performed by individually considering men and women (Table IV), in which the test samples related to the variable women showed no statistically significant differences for the landmarks studied $(\mathrm{p}<0.05)$ (Table V). In addition, there were also no significant differences for the variable men $(\mathrm{p}<0.05)$ (Table $\mathrm{VI})$.

\section{DISCUSSION}

It will probably never be possible to describe and predict the enormous number of variations of the face.

Tabla II. Statistics for related samples in total sample.

\begin{tabular}{llcccc}
\hline & & Mean & n & SD & SE Mean \\
\hline Pair 1 & Left Superciliary & 5.691 & 32 & 0.4343 & 0.0768 \\
& Right Superciliary & 5.781 & 32 & 0.4192 & 0.0741 \\
Pair 2 & Left Supraorbital & 6.488 & 32 & 1.1056 & 0.1954 \\
& Right Supraorbital & 6.625 & 32 & 1.0857 & 0.1919 \\
Pair 3 & Left Exocanthion & 3.950 & 32 & 0.3852 & 0.0681 \\
& Right Exocanthion & 4.00 & 32 & 0.415 & 0.073 \\
Pair 4 & Left Infraorbital & 5.378 & 32 & 1.4633 & 0.2587 \\
& Right Infraorbital & 5.366 & 32 & 1.3830 & 0.2445 \\
Pair 5 & Left Zygion & 6.77 & 32 & 2.351 & 0.416 \\
& Right Zygion & 6.800 & 32 & 2.3316 & 0.4122 \\
Pair 6 & Left Gonion & 10.40 & 32 & 4.638 & 0.820 \\
& Right Gonion & 10.39 & 32 & 4.642 & 0.821 \\
\hline
\end{tabular}

However, it is necessary to study the relationship between the skull and facial characteristics, and the knowledge of facial soft-tissue thickness is an inseparable part of these studies.

In recent years, there has been a significant increase in studies on the determination of facial soft-tissue thicknesses for forensic reconstruction. Research on facial-tissue depth has been performed in children, adolescents (Wilkinson; Utsuno et al., 2005), and mainly adults (El-Mehallawi \& Soliman; Suazo et al., 2007a, 2007b, 2008; Barriga et al., 2010). Most of the current techniques of facial reconstruction are based on the same method, with the implementation of elements that constitute the soft tissue on the skull, resulting in the formation of a face, where the facial soft tissues represent muscles, subcutaneous tissue, and skin.

Forensic reconstruction of a perfect face that is bilaterally symmetrical is almost a theoretical concept, because it rarely occurs in nature (Panenková, 2007). A mild degree of facial asymmetry is not obvious and may even play a positive role in human attraction, but marked malformation or scarring of the face can cause severe psychosocial impact, hindering a correct reconstruction (Huisinga-Fischer et al., 2004).

In our study, the total sample showed no significant difference in thickness between left and right sides ( $p>0.05$ ). In a similar study on Caucasians, De Greef et al. (2006) reported the following landmarks for the left and right sides, respectively: superciliary $=4.1$ and $4 \mathrm{~mm}$; supraorbital $=5.6$ and $5.4 \mathrm{~mm}$; infraorbital $=9.5$ and $9.4 \mathrm{~mm}$; zygion $=6.5$ and $6.7 \mathrm{~mm}$; exocathion $=8.9$ and $9.4 \mathrm{~mm}$; and gonion $=14.2$ and 15.1 $\mathrm{mm}$. None of the measures showed a significant difference. Among the studies on other

Tabla III. Test for related samples in total sample.

\begin{tabular}{|c|c|c|c|c|c|c|c|c|}
\hline & \multicolumn{5}{|c|}{ Paired differences } & \multirow[t]{3}{*}{$\mathbf{t}$} & \multirow[t]{3}{*}{ df } & \multirow[t]{3}{*}{ Sig. (2-tailed) } \\
\hline & \multirow[b]{2}{*}{ Mean } & \multirow[b]{2}{*}{ SD } & \multirow[b]{2}{*}{ SE Mean } & \multicolumn{2}{|c|}{$\begin{array}{l}95 \% \text { confidence interval for } \\
\text { the difference }\end{array}$} & & & \\
\hline & & & & Lower & Upper & & & \\
\hline Pair 1 & -.0906 & .4145 & .0733 & -.2401 & .0588 & -1.237 & 31 & .225 \\
\hline Pair 2 & -.1375 & .5173 & .0914 & -.3240 & .0490 & -1.504 & 31 & .143 \\
\hline Pair 3 & -.0531 & .2342 & .0414 & -.1375 & .0313 & -1.283 & 31 & .209 \\
\hline Pair 4 & .0125 & .7052 & .1247 & -.2417 & .2667 & .100 & 31 & .921 \\
\hline Pair 5 & -.0281 & .5081 & .0898 & -.2113 & .1551 & -.313 & 31 & .756 \\
\hline Pair 6 & .009 & .364 & .064 & -.122 & .141 & .146 & 31 & .885 \\
\hline
\end{tabular}


TORRES M. S. R.; CANTIN, M.; PÉREZ R. F. J. \& SUAZO, G. I. Evaluation of facial asymmetry using soft-tissue thickness for forensic purposes. Int. J. Morphol., 29(3):1033-1039, 2011.

Tabla IV. Statistics for related samples for Women and Men independently.

\begin{tabular}{llcccccccc}
\hline & & \multicolumn{3}{c}{ Women } & \multicolumn{3}{c}{ Men } \\
\cline { 3 - 8 } & & $\mathbf{n}$ & Mean & SD & SE Mean & n & Mean & SD & SE Mean \\
\hline Pair 1 & Left Superciliary & 16 & 5.569 & 0.2983 & 0.0746 & 16 & 5.813 & 0.5188 & 0.1297 \\
& Right Superciliary & 16 & 5.750 & 0.4733 & 0.1183 & 16 & 5.813 & 0.3704 & 0.0926 \\
Pair 2 & Left Supraorbital & 16 & 6.119 & 0.6112 & 0.1528 & 16 & 6.856 & 1.3648 & 0.3412 \\
& Right Supraorbital & 16 & 6.169 & 0.5582 & 0.1396 & 16 & 7.081 & 1.2963 & 0.3241 \\
Pair 3 & Left Exocanthion & 16 & 3.938 & 0.3222 & 0.0806 & 16 & 3.963 & 0.4500 & 0.1125 \\
& Right Exocanthion & 16 & 4.01 & 0.423 & 0.106 & 16 & 4.00 & 0.420 & 0.105 \\
Pair 4 & Left Infraorbital & 16 & 4.950 & 1.2796 & 0.3199 & 16 & 5.806 & 1.5481 & 0.3870 \\
& Right Infraorbital & 16 & 4.988 & 1.2511 & 0.3128 & 16 & 5.744 & 1.4431 & 0.3608 \\
Par 5 & Left Zygion & 16 & 6.04 & 0.839 & 0.210 & 16 & 7.51 & 3.093 & 0.773 \\
& Right Zygion & 16 & 5.994 & 0.8070 & 0.2018 & 16 & 7.606 & 3.0326 & 0.7581 \\
Pair 6 & Left Gonion & 16 & 13.30 & 4.318 & 1.080 & 16 & 7.51 & 2.812 & 0.703 \\
& Right Gonion & 16 & 13.35 & 4.295 & 1.074 & 16 & 7.44 & 2.728 & 0.682 \\
\hline
\end{tabular}

Tabla V. Test for related samples in Women.

\begin{tabular}{|c|c|c|c|c|c|c|c|c|}
\hline & \multicolumn{5}{|c|}{ Paired differences } & \multirow[t]{3}{*}{$\mathbf{t}$} & \multirow[t]{3}{*}{ df } & \multirow[t]{3}{*}{ Sig. (2-tailed) } \\
\hline & \multirow{2}{*}{ Mean } & \multirow{2}{*}{ SD } & \multirow{2}{*}{ SE Mean } & \multicolumn{2}{|c|}{$\begin{array}{l}95 \% \text { confidence interval for } \\
\text { the difference }\end{array}$} & & & \\
\hline & & & & Lower & Upper & & & \\
\hline Pair 1 & -.1813 & .5319 & .1330 & -.4647 & .1022 & -1.363 & 15 & .193 \\
\hline Pair 2 & -.0500 & .3246 & .0811 & -.2229 & .1229 & -.616 & 15 & .547 \\
\hline Pair 3 & -.0688 & .2575 & .0644 & -.2059 & .0684 & -1.068 & 15 & .302 \\
\hline Pair 4 & -.0375 & .6021 & .1505 & -.3583 & .2833 & -.249 & 15 & .807 \\
\hline Pair 5 & .0438 & .4647 & .1162 & -.2039 & .2914 & .377 & 15 & .712 \\
\hline Pair 6 & -.050 & .473 & .118 & -.302 & .202 & -.423 & 15 & .679 \\
\hline
\end{tabular}

Tabla VI. Test for related samples in Men.

\begin{tabular}{|c|c|c|c|c|c|c|c|c|}
\hline & \multicolumn{5}{|c|}{ Paired differences } & \multirow[t]{3}{*}{$\mathbf{t}$} & \multirow[t]{3}{*}{ df } & \multirow[t]{3}{*}{ Sig. (2-tailed) } \\
\hline & \multirow{2}{*}{ Mean } & \multirow{2}{*}{ SD } & \multirow{2}{*}{ SE Mean } & \multicolumn{2}{|c|}{$\begin{array}{l}95 \% \text { confidence interval for } \\
\text { the difference }\end{array}$} & & & \\
\hline & & & & Lower & Upper & & & \\
\hline Pair 1 & .0000 & .2338 & .0585 & -.1246 & .1246 & .000 & 15 & 1.000 \\
\hline Pair 2 & -.2250 & .6568 & .1642 & -.5750 & .1250 & -1.370 & 15 & .191 \\
\hline Pair 3 & -.0375 & .2156 & .0539 & -.1524 & .0774 & -.696 & 15 & .497 \\
\hline Pair 4 & .0625 & .8123 & .2031 & -.3703 & .4953 & .308 & 15 & .762 \\
\hline Pair 5 & -.1000 & .5538 & .1384 & -.3951 & .1951 & -.722 & 15 & .481 \\
\hline Pair 6 & .069 & .206 & .051 & -.041 & .178 & 1.337 & 15 & .201 \\
\hline
\end{tabular}

populations using the puncture needle technique, in a Spanish population with normal BMI, Valencia (2007) reported the following average values for the landmarks: supraorbital $=$ $6.7 \mathrm{~mm}$; infraorbital $=7.5 \mathrm{~mm}$; zygion $=8.8 \mathrm{~mm}$; and gonion $=12.7 \mathrm{~mm}$. Furthermore, Villanueva et al. (2006), in Mexican population of normal BMI, reported the following average values for the landmarks: supraorbital $=6.8 \mathrm{~mm}$; infraorbital $=7.2 \mathrm{~mm} ;$ zygion $=8.5 \mathrm{~mm} ;$ and gonion $=14.1$ mm, while Rhine \& Campbell, in a Caucasian American population, reported the following average values for the landmarks: supraorbital $=8.3 \mathrm{~mm}$; infraorbital $=5.8 \mathrm{~mm}$; zygion $=7.3 \mathrm{~mm}$; and gonion $=11.5 \mathrm{~mm}$. However, none of the authors examined the differences between left and right sides of the face. 
Lee et al. (2009) reported that in cases of symmetrical craniosynostosis, the thickness of right and left soft facial tissues is identical. However, in asymmetrical craniosynostosis, the thickness of soft tissues in the hypoplastic side is much less, from both the front and side ( $\mathrm{p}$ $=0.048$ and $\mathrm{p}=0.034$, respectively). This suggests that surgeons should pay attention to the asymmetry of the soft tissues during follow-up and time to correct facial asymmetry in asymmetric craniosynostosis.

However, Sahni et al. (2008) determined the facial tissue thickness in 173 men and 127 women using MRI and found a slight asymmetry in the majority of bilateral landmarks, where measurements of the left side were greater than those of the right side, while previous studies had found only a single asymmetric reference point at the left side (Domaracki \& Stephan, 2006) or greater thickness measurements on the right side (Sutton, 1969). With regard to these conflicting results, Hager \& Ekman (1985) argued that facial regions are asymmetrical when presented with a facial expression of the normal face. Accordingly, we can explain the lack of significant asymmetry in our measures, as in the living subjects mentioned in Sahni et al. who have used facial expression, while in most of the literature and in our study, cadavers are used with lack of facial expression.

When analyzing the differences according to sex, women showed no significant difference. In the Portuguese population of women with normal BMI, Codinha (2009), using the needle puncture technique reported the following average values for the landmarks: supraorbital $=7.3 \mathrm{~mm}$ (SD 1.2, range 5.5-9), infraorbital $=7.8 \mathrm{~mm}$ (SD 2.1, range $5-11.5)$, zygion $=8.9 \mathrm{~mm}(\mathrm{SD} 1.5$, range $6.5-11.5)$, and gonion $=11.9 \mathrm{~mm}(\mathrm{SD} 2.2$, range $8.5-15)$; however, these results only correspond to the right face. Sahni et al., using MRI (in 127 adult Indian women), reported the following average values for the landmarks on right and left sides, respectively: superciliary $=4.09$ and $4.23 \mathrm{~mm}$; supraorbital $=6.42$ and $6.58 \mathrm{~mm}$; infraorbital $=4.40$ and $4.56 \mathrm{~mm}$; exocanthion $=4.38$ and $4.57 \mathrm{~mm}$; and gonion $=15.05$ and $15.30 \mathrm{~mm}$. According to Rhine and Campbell, in women, the average values for the landmarks on right and left sides, respectively, are as follows: superciliary $=8.75$ and 8.25 $\mathrm{mm}$; supraorbital $=4.75$ and $4.75 \mathrm{~mm}$; infraorbital $=7.75$ and $7.50 \mathrm{~mm}$; exocanthion $=13.25$ and $13.00 \mathrm{~mm}$; and, gonion $=14.75$ and $14.25 \mathrm{~mm}$.

In our results, on analyzing the left and right sides in men, no differences were observed. This is consistent with Codinha, who reported the following average values for the landmarks in men with normal BMI: supraorbital $=7.4 \mathrm{~mm}$ (SD 1.3, range 5-10); infraorbital $=8.1 \mathrm{~mm}(\mathrm{SD} 2.5$, range $4-15.5)$; zygion $=7.9 \mathrm{~mm}$ (SD 2.4 and range 4.5-13); and gonion $=14.2 \mathrm{~mm}(\mathrm{SD} 3.8$ range $8-22.5)$. Sahni et al., on studying $173 \mathrm{men}$, reported the following values: superciliary $=4.30$ and $4.16 \mathrm{~mm}$; supraorbital $=7.08$ and $6.90 \mathrm{~mm}$; infraorbital $=4.47$ and $4.61 \mathrm{~mm}$; gonion $=15.67$ and 15.34 $\mathrm{mm}$; and exocanthion $=4.64$ and $4.46 \mathrm{~mm}$. According to Rhine \& Campbell, in men the following average values for the landmarks on the right and left sides, respectively, were observed: superciliary $=8.25$ and $8.75 \mathrm{~mm}$; supraorbital $=$ 4.75 and $4.75 \mathrm{~mm}$; infraorbital $=7.5$ and $7.75 \mathrm{~mm}$; gonion = 14.25 and $14.75 \mathrm{~mm}$; and exocanthion $=13.0$ and 13.25 .

As expected, in our study and those reported in the literature, there was no variation in relation to natural sexual dimorphism (Rhine \& Campbell; Villanueva et al.; Domaracki \& Stephan; De Greef, et al., 2006; Barriga et al.).

Although it is empirically observable that facial tissues thicken with an increase in weight, studies have determined that the distribution and accumulation of adipose tissue along different portions of the face are very much variable, not only between the sexes, but also within the sexes. In this regard, some authors argue that variations in the depth of facial soft tissues are not significant in relation to the BMI, or the right and left sides (De Greef et al., 2009; Stephan et al., 2005).

In terms of asymmetry, it is well known that expressions cause a considerable amount of facial asymmetry, which is more intense on the left side of the face (Mitra et al., 2005). Liu et al. first showed that facial asymmetry measures are efficient tools for human identification under expression variations. This was followed by further studies in humans, and the classification of expression (Mitra \& Liu). However, for facial reconstruction, facial asymmetry is not a point of variation.

The craniofacial morphology is a complex association between heredity and environmental factors (Baydas, et al., 2007). If the skull is considered as a mechanical support for the face and if we assume that the shape of the skull morphology predetermines the shape of the head and face, as well as the appearance, then measuring the distance between precisely defined points in the skull and reference landmarks of the face can lead to an approximate recreation of the face (Iscan). In conclusion, facial morphology is created in vivo by external and internal forces exerted on the soft tissues and is influenced by their evolutionary development (Rynn \& Wilkinson, 2006), where asymmetric parameters have a genetic (Oki et al.; Schlueter \& Brand) and muscular (Ciochon et al.; Kiliaridis et al.) determination, which in normal individuals do not represent a significant difference in the process of reconstruction of forensic sculpture, and can reliably standardize the entire information of facial thickness to the right or left side of the face. 
TORRES M. S. R.; CANTIN, M.; PÉREZ R. F. J. \& SUAZO, G. I. Evaluación de la asimetría facial mediante el grosor de tejidos blandos para propósitos forenses. Int. J. Morphol., 29(3):1033-1039, 2011.

RESUMEN: La reconstrucción facial por escultura forense tiene por finalidad reproducir el rostro de un individuo para su identificación. Esta técnica se sustenta en el conocimiento del grosor del tejido blando facial; el cual presenta diferencias en términos de dimorfismo sexual. Sin embargo, en términos de asimetría, no se ha considerado la real significancia del espesor de tejido blando a ambos lados del rostro al realizar una aproximación de las características morfofaciales de un individuo. En este estudio se analizaron los grosores tisulares faciales de 32 cadáveres españoles adultos de ambos sexos en 6 puntos cefalométricos paramedianos bilateralmente mediante el método de punción por agujas, comparando las mediciones del lado derecho e izquierdo. No se encontraron diferencias significativas al comparar el espesor del tejido facial en el lado derecho e izquierdo en el total de la muestra ( $p<0,05)$, así como al comparar los valores en hombres y mujeres $(\mathrm{p}<0,05)$. La morfología facial es creada in vivo por fuerzas internas y externas ejercidas sobre el tejido blando e influenciada por su desarrollo evolutivo, donde parámetros de asimetría tienen una determinación genética y muscular, que en individuos normales no representan una diferencia significativa para el proceso de reconstrucción por escultura forense, pudiendo homologar de manera confiable la totalidad de la información del grosor facial del lado derecho o izquierdo del rostro.

PALABRAS CLAVE: Asimetría facial; Reconstrucción facial; Grosor Tisular; Identificación médicolegal.

\section{REFERENCES}

American Board of Forensic Anthropology Inc. ABFA website, 2003. Available in: www.csuchico.edu/anth/ABFA

Baydas, B.; Erdem, A.; Yavuz, I. \& Ceylan, I. Heritability of facial proportions and soft-tissue profile characteristics in Turkish Anatolian siblings. Am. J. Orthod. Dentofacial Orthop., 131(4):504-9, 2007.

Barriga, S. C.; Zavando, M. D.; Cantín, L. M. \& Suazo, G. I. Facial tissue thickness in Chilean cadavers with medicolegal purposes. Int. J. Odontostomat., 4(3):215-22, 2010.

Brennan, M. \& Antonyshyn, O. The effects of temporalis muscle manipulation on skull growth: an experimental study. Plast. Reconstr. Surg., 97(1):13-24, 1996.

Ciochon, R. L.; Nisbett, R. A. \& Corruccini, R. S. Dietary consistency and craniofacial development related to masticatory function in minipigs. J. Craniofac. Genet. Dev. Biol., 17(2):96-102, 1997.

Codinha, S. Facial soft tissue thicknesses for the Portuguese adult population. Forensic Sci. Int., 184(1-3):80.e1-7, 2009 .

De Greef, S.; Vandermeulen, D.; Claes, P.; Suetens, P. \& Willems, $\mathrm{G}$. The influence of sex, age and body mass index on facial soft tissue depths. Forensic Sci. Med. Pathol., 5(2):60-5, 2009.

De Greef, S.; Claes, P.; Vandermeulen, D.; Mollemans, W.; Suetens, P. \& Willems, G. Large-scale in-vivo Caucasian facial soft tissue thickness database for craniofacial reconstruction. Forensic Sci. Int., 159(Suppl 1):S126-46, 2006.
Dumont, E. R. Mid-facial tissue depths of white children: an aid in facial feature reconstruction. J. Forensic Sci., 31(4):1463-9, 1986.

Domaracki, M. \& Stephan, C. N. Facial soft tissue thicknesses in Australian adult cadavers. J. Forensic Sci., 51(1):5-10, 2006.

El-Mehallawi, I. H. \& Soliman, E. M. Ultrasonic assessment of facial soft tissue thicknesses in adult Egyptians. Forensic Sci. Int., 117(1-2):99-107, 2001.

Fink, B. \& Neave, N. The biology of facial beauty. Int. J. Cosmet. Sci., 27(6):317-25, 2005.

Hager, J. C. \& Ekman, P. The asymmetry of facial actions is inconsistent with models of hemispheric specialization. Psychophysiology, 22(3):307-18, 1985.

Huisinga-Fischer, C. E.; Souren, J. P.; Werken, F.; PrahlAndersen, B. \& van Ginkel, F. Perception of symmetry in the face. J. Craniofac. Surg., 15(1):128-34, 2004.

Iscan, M. Y.: Concepts in teaching forensic anthropology. Medical Anthropol. Newsletter, 13(1):10-12,1981.

Kiliaridis, S.; Bresin, A.; Holm, J. \& Strid, K. G. Effects of masticatory muscle function on bone mass in the mandible of the growing rat. Acta Anat., 155(3):200-5, 1996.

Koehler, N.; Simmons, L. W.; Rhodes, G. \& Peters, M. The relationship between sexual dimorphism in human faces and fluctuating asymmetry. Proc. Biol. Sci., 271(Suppl 4):S2336, 2004.

Lee, D. W.; Rah, D. K.; Park, B. Y. \& Kim, Y. O. Comparison of the soft tissue thickness of the midface in craniosynostosis. J. Craniofac. Surg., 20(6):2259-62, 2009. 
Liu Y.; Schmidt, K.; Cohn, J. \& Weaver, R. L. Human facial asymmetry for expression-invariant facial identification. In: Proceedings of the Fifth IEEE International Conference on Automatic Face and Gesture Recognition, 2002.

Manhein, M. H.; Listi, G. A.; Barsley, R. E.; Musselman, R.; Barrow, N. E. \& Ubelaker, D. H. In vivo facial tissue depth measurements for children and adults. J. Forensic Sci., 45(1):48-60, 2000.

Meyer-Marcotty, P.; Alpers, G. W.; Gerdes, A. B. \& StellzigEisenhauer, A. Impact of facial asymmetry in visual perception: a 3-dimensional data analysis. Am. J. Orthod. Dentofacial Orthop., 137(2):168-9, 2010.

Mitra, S. \& Liu, Y. Local facial asymmetry for expression classification. In: Proceedings of IEEE Conference on Computer Vision and Pattern Recognition (CVPR), 2004.

Mitra, S.; Savvides, M. \& Kumar, B. V. K. V. Facial Asymmetry: A New Robust Biometric in the Frequency Domain. Lecture Notes in Computer Science, 1065-72, 2005.

Oki, S.; Kitajima, K.; Marques, S.; Belo, J. A.; Yokoyama, T.; Hamada, H. \& Meno, C. Reversal of left-right asymmetry induced by aberrant Nodal signaling in the node of mouse embryos. Development, 136(23):3917-25, 2009.

Panenková, P. Face approximation and information about facial soft tissue thickness. EAA Summer School eBook, 1:233-9, 2007.

Perrett, D. I.; Lee, K. J.; Penton-Voak, I.; Rowland, D.; Yoshikawa, S.; Burt, D. M., Henzi, S. P.; Castles, D. L. \& Akamatsu, S. Effects of sexual dimorphism on facial attractiveness. Nature, 394(6696):884-7, 1998.

Romo Pizarro, O. Medicina Legal Elementos de Ciencias Forenses. Santiago de Chile, Edit. Jurídica de Chile, 2000.

Rynn, C. \& Wilkinson, C. M. Appraisal of traditional and recently proposed relationships between the hard and soft dimensions of the nose in profile. Am. J. Phys. Anthropol., 130(3):364$73,2006$.

Rhine, J. S. \& Campbell, H. R. Thickness of facial tissues in American blacks. J. Forensic Sci., 25(4):847-58, 1980.

Schlueter, J. \& Brand, T. Left-right axis development: examples of similar and divergent strategies to generate asymmetric morphogenesis in chick and mouse embryos. Cytogenet. Genome Res., 117(1-4):256-67, 2007.

Sahni, D.; Sanjeev; Singh, G.; Jit, I. \& Singh, P. Facial soft tissue thickness in northwest Indian adults. Forensic Sci. Int., 176(2-3):137-46, 2008.
Smith, S. L. \& Buschang, P. H. Midsagittal facial tissue thicknesses of children and adolescents from the Montreal growth study. J. Forensic Sci., 46(6):1294-302, 2001.

Stephan, C. N.; Norris, R. M. \& Henneberg, M. Does sexual dimorphism in facial soft tissue depths justify sex distinction in craniofacial identification? J. Forensic Sci., 50(3):513-8, 2005.

Suazo, G. I. C; Pérez, R. F. J. \& Torres, M. S. R. Grosores Tisulares Faciales en Cadáveres de Españoles y su Aplicación en la Identificación Médicolegal. Int. J. Morphol., 25:109-16, 2007a.

Suazo, G. I. C.; Salgado, A. G. E. \& Cantín, L. M. G. Evaluación ultrasonográfica del tejido blando facial en adultos chilenos. Int. J. Morphol., 25:643-648, 2007b.

Suazo, G. I. C.; Cantín, L. M.; Zavando, M. D. A.; Perez, R. F. J. \& Torres, M. S. R. Comparisons in soft-tissue thickness on the human face in fresh and embalmed corpses using needle puncture method. Int. J. Morphol., 26:165-9, 2008.

Sutton, P. R. Bizygomatic diameter: the thickness of the soft tissues over the zygions. Am. J. Phys. Anthropol., 30(2):30310, 1969.

Teke, A. Medicina Legal y Criminalística. Santiago de Chile, Editorial Jurídica de Santiago, 2004.

Utsuno, H.; Kageyama, T.; Uchida, K.; Yoshino, M.; Miyazawa, H. \& Inoue, K. Facial soft tissue thickness in Japanese children. Forensic Sci. Int., 199(1-3):109.e1-6, 2010.

Valencia, L. Metodologia para elaborar reconstrucciones faciales empleando gráficos computorizados tridimensionales. Laboratorio de Antropología, Universidad de Granada, 2007.

Villanueva, M.; Serrano, C. Escorcia, L. Valencia, L. Grosor de tejido blando en una serie Mexicana. Antropol. Fis. Latinoam., 4:231-45, 2006.

Wilkinson, C. M. In vivo facial tissue depth measurements for white British children. J. Forensic Sci., 47(3):459-65, 2002

Correspondence to:

Sebastián René Torres Muñoz

Departamento de Ciencias Básicas Biomédicas

Universidad de Talca

Avenida Lircay s/n, Talca

CHILE

Email: storres@sceo.cl

Recibido : 14-07-2011

Aceptado: 29-07-2011 